astronomy was awakened by contact with such inspiring teachers as W. W. Payne and H. C. Wilson. In 1899 he was appointed professor of mathematics at Fargo College (North Dakota). It was here that the problem of terrestrial magnetism first engaged his attention and he devoted his summer vacations (1904-6) to magnetic observations for the United States Coast and Geodetio Survey in the north-central and western States. His interest in this field grew so rapidly that in October 1906 he adopted it as his life work when he became associated with the Department of Terrestrial Magnetism.

Here Prof. Fisk focused his activities on the land magnetic survey-one of the major undertakings of the Department. He made two detailed surveys of the Bermuda Islands, in 1907 and 1922, and in 1908 conducted magnetic expeditions in Central America, in the West Indies, and in the northern countries of South America. He was also greatly interested in the investigations of possible eclipse effects on the earth's magnetic field and participated in several eclipse expeditions of the Department--the last was on the occasion of the eclipse of August 21, 1932, when he was in charge of three observing parties in New England. He took a prominent place in the instruction of many of the Department's most active observers and in the laborious observations during many years in Washington, D.C., relating to the control of instrumental outfits and the determination of the provisional international magnetic standards.

Prof. Fisk's chief research contribution was the investigation of secular changes in the earth's magnetism and of the shifting of isoporic foci disclosed by magnetic data obtained at strategic repeat-stations by observers under his supervision. Mature deliberation led him to infer that secular changes in the earth's magnetism determined by observations on its surface might reflect changes within the earth's crust or interior. At the time of his death, he had in preparation an exhaustive paper on this subject.

Besides membership of a number of scientific societies, Prof. Fisk was an active worker in the American Geophysical Union, being secretary of its Section of Terrestrial Magnetism and Electricity in 1929-32. Because of an unusual breadth of culture extending far beyond the confines of his scientific activity, it was his pleasure and privilege to render important service to his community in its civic and religious life. His quiet disposition, generous nature, and helpful counsel, won him the esteem of his colleagues and friends. Those who shared his acquaintance and work, will mourn with his widow and four children his premature passing.

H. D. Harradon

\section{Mr. B. H. Soulsby}

Mr. B. H. Soursby, who died at Reading on January 14, aged sixty-eight, was for nearly thirty-eight years in the service of the Trustees of the British Museum, first at Bloomsbury and later at South Kensington. He was educated at Cheltenham College and at Corpus Christi College, Oxford, and also studied at Göttingen. He entered the service of the Trustees as a second-class assistant in the Department of Printed Books in 1892, and became successively superintendent of the Map Room, of the Copyright Office, and finally deputy superintendent of the Reading Room. During his time at Bloomsbury, he catalogued the library of the Grand Priory of the Order of the Hospital of St. John of Jerusalem in England, and translated some early geographical works. In 1902 he published a small pamphlet on the earliest two maps which bear the name America.

In $1909 \mathrm{Mr}$. Soulsby was transferred to the Natural History Museum as assistant in the Director's office, and in January 1921 he was appointed librarian in succession to the late $\mathrm{Mr}$. B. B. Woodward. His principal official duty was to continue Woodward's Catalogue of the Natural History Library, a monument of bibliographical care and research and a mine of information, the value of which was recognised far beyond the limits of the Library to which the work refers. Woodward had compiled six volumes and one supplementary volume, and at the time of Mr. Soulsby's retirement, the second supplementary volume was well on the way to completion.

At the time of his death, Mr. Soulsby was seeing through the press the final stages of a revised, second edition of the "Catalogue of the Works of Linnaus ... in the British Museum". The first edition, which was compiled by B. B. Woodward and W. R. Wilson, was a quarto publication of 27 pages, comprising some 580 entries. The second edition will contain about 300 pages of text, with nearly four thousand entries, accompanied by bibliographical notes, plates and an index.

It was upon this index that Mr. Soulsby was engaged, with his accustomed industry and enthusiasm, at the time of his death. The forthcoming publication of this Linnæan Catalogue is a matter of great interest to librarians in Sweden, from several of whom Mr. Soulsby obtained considerable assistance in its preparation. The compiler used to claim that the collection of Linnæana at South Kensington was second only in richness and importance to that at the Royal University Library of Uppsala, and if this is so, it is largely due to Mr. Soulsby's great generosity, inasmuch as ever since he undertook the work of producing a second edition of this catalogue, he was continually presenting rare and costly Linnxana to the library at South Kensington.

\section{Mr. J. L. S. HATTON}

John Leigh Smeathman Hatron, who died on January 13, aged sixty-seven years, was the first principal of East London College and, at the time of his death, Vice-Chancellor of the University of London. He was born at Street Aston on May 27, 1865, the son of the Rev. J. L. S. Hatton, 